\title{
Kemoterapi ve Radyoterapi Alan Kanserli Bireylerde Yorgunluk ve Spiritüel İyilik Hali: Tanımlayıcı-Korelasyonel Bir Çalışma
}

\section{Fatigue and Spiritual Well-being in Cancer Individuals Receiving Chemotherapy and Radiotherapy: A Descriptive-Correlational Study}

\author{
Nur İzgü ${ }^{1 *}$, Zehra Gök Metin ${ }^{1}$ \\ ${ }^{1}$ Hacettepe Üniversitesi Hemşirelik Fakültesi İç Hastalıkları Hemşireliği Anabilim Dalı, Ankara, Türkiye \\ e-posta: akglnur@gmail.com,zehragok85@hotmail.com \\ ORCID: 0000-0001-6343-5923 \\ ORCID: 0000-0003-0311-9982 \\ *Sorumlu yazar/Corresponding author: Nur İzgü ${ }^{1}$ \\ Gönderim tarihi/Received:03.02.2020 \\ Kabul tarihi/Accepted:11.05.2020 \\ DOI:10.34087/cbusbed.684123

\section{Öz}

Giriș ve Amaç: Bu araştırmanın amacı, kanserli bireylerde yorgunluk ve spiritüel iyilik hali arasındaki ilişkiyi incelemektir.

Gereç ve Yöntemler: Tanımlayıc1-korelasyonel tasarımla yürütülen bu araştırmaya 10 Haziran-25 Temmuz 2019 tarihleri arasında bir kamu üniversitesi hastanesinde kemoterapi ve/veya radyoterapi alan kanserli bireyler $(\mathrm{n}=129)$ dahil edilmiştir. Araştırma verilerinin toplanmasında Kişisel Bilgi Formu, Kronik Hastalık Tedavisi Fonksiyonel Değerlendirmesi (FACIT) Yorgunluk Ölçeği ve FACIT Spiritüel İyilik Hali (FACIT-Sp) ölçeği kullanılmıştır.

Bulgular: Araştırmada hem yorgunluk şiddeti hem de spiritüel iyilik hali puan ortancası 34 olarak belirlenmiştir. Erkek, ileri evre kanser tanısına sahip ve komorbid hastalığ bulunan bireylerde yorgunluk şiddeti anlamlı düzeyde yüksek bulunmuştur $(\mathrm{p}<0,05)$. Bireylerin tanımlayıcı özelliklerine göre spiritüel iyilik hali puanları arasında anlamlı bir farklılık bulunmamıştır ( $p>0,05)$. FACIT Yorgunluk Ölçeği ve FACIT-Sp Ölçeği toplam puanları arasında pozitif yönde zayıf düzeyde bir korelasyon olduğu belirlenmiştir $(\mathrm{p}<0,001)$.

Sonuç: Araştırmada yorgunluğun cinsiyet, kanser evresi ve komorbid hastalık varlığından etkilendiği, yorgunluk şiddeti azaldıkça spiritüel iyilik halinin arttığı sonucuna ulaşılmıştır. Araştırma sonuçlarından hareketle; onkoloji hemşirelerinin kanser ilişkili yorgunluğu değerlendirirken bireylerin spiritüel iyilik hali ve spiritüel bakım gereksinimlerini de göz önünde bulundurmaları, spesifik kanser türü ve evrelerini ele alan ileri prospektif araștırmaların yapılması önerilmiștir.

Anahtar kelimeler: Kanser, yorgunluk, spiritüelite, iyilik, hemşirelik.

Abstract
Objective: The aim of this study was to investigate correlation between fatigue and spirituel well-being in individuals with cancer.

Materials and Methods: This descriptive correlational study was conducted in individuals with cancer $(n=129)$ receiving chemotherapy and/or radiotherapy in a public university hospital between 10 June and 25 July 2019. Personal Information Form, Functional Assesment of Cancer Therapy (FACIT) Fatigue Scale and FACIT Spirituel Well-being (FACIT-Sp) Scale were utilized to collect data.

Results: In the study, both fatigue severity and spiritual well-being median scores were calculated as 34 . Fatigue severity was significantly higher in male, individuals with advanced-stage cancer and comorbid disease $(\mathrm{p}<0.05)$. Spiritual well-being scores did not significantly differ according to descriptive characteristics of the study sample $(\mathrm{p}>0.05)$. A positive and weak correlation was found between the FACIT fatige scale and FACIT-Sp scale scores $(\mathrm{p}<0.001)$.

Conclusion: This study concluded that perceived fatigue severity was affected by gender, stage of cancer, and presence of any comorbid disease, and as fatigue severity decreased, spiritel well-being increased. Moving from the study results, oncology nurses are recommended to consider spiritüel well-being and spiritel care needs of individuals 
during cancer related fatigue assessment, and further prospective studies addressing specific type and cancer stages are suggested.

Key words: Cancer, fatigue, spirituality, well-being, nursing.

\section{Giriș}

Kanser ilişkili yorgunluk, kanser tedavisi alan ve tedavi sonrası sağ kalan bireylerde sık görülen ve yaşam

kalitesini olumsuz etkileyen rahatsı edici bir semptomdur. Literatürde kanser ilişkili yorgunluk prevelansının \%59-100 olduğu rapor edilmiștir [1]. Kanser ilişkili yorgunluk hastalar tarafından halsizlik, bitkinlik, tükenmişlik, ağırlık hissi, çabuk yorulma, yavaşlama, enerji azlığı ya da yokluğu, uyuşukluk ve dermansızlık gibi kelimelerle tanımlanabilmektedir [2]. Ulusal Kapsamlı Kanser Ağı tarafindan yorgunluk; kanser ya da tedavisine bağlı ortaya çıkan, aktivite ile ilişsisi olmayan ve fonksiyonel durumu olumsuz etkileyen sıkıntı verici ve inatçı bir halsizlik ya da tükenmişlik hissi olarak tanımlanmıştır [3,4]. Kanser ilişkili yorgunluk; çok boyutlu, subjektiif ve yönetimi oldukça zor olan bir semptomdur. Literatürde kanser hastalarında görülen yorgunluğun etiyolojisinde kanser türü, evresi, tanı süresi, uygulanan kanser tedavileri, ağr1, iştahsızlık, bulantı-kusma, yetersiz beslenme, uyku bozuklukları, anemi, hipoksemi, enfeksiyonlar ve eşlik eden diğer kronik rahatsızlıkların etkili olabileceğ bildirilmiştir [3,5]. Ayrıca, kanser tanılı bireylerde etkili şekilde yönetilemeyen yorgunluk zamanla genel güçsüzlük, konsantrasyon güçlüğü veya dikkat azalması, günlük yaşam aktivitelerine karşı ilgi ve motivasyonda azalma, uyku sorunları, baş etmede yetersizlik, bitkinlik, hayal kırıklığı ve huzursuzluk gibi duygusal tepkiler, mesleki yaşam, aile ve çevre olan ilişkilerde bozulma, cinsel yaşamda güçlükler fonksiyonel kapasitenin azalmasından dolayı günlük yaşam aktivitelerinde başka kişilere bağımlı olma, anksiyete ve depresyon gibi ek sorunlara yol açarak bireylerin üzerinde fiziksel, psikolojik ve sosyo-ekonomik açıdan pek çok yıkıcı etkiye yol açabilmektedir[6-8]. Kanser ilişkili yorgunluk; duygusal, bilişsel, sosyal ve ekonomik değişikliklere neden olarak bireyin yaşam kalitesini olumsuz etkileyebilmektedir [9-11]. Klinik bir araştırmada; yorgunluk yaşadığını belirten kanserli bireylerin yorgunluk nedeniyle günlük rutinlerini değiştirdikleri, uzak mesafe yürüme, merdiven çıkma ve yemek hazırlama gibi günlük aktivitelerini gerçekleştirmede güçlük yaşadıkları bildirilmiştir [9]. Buna ek olarak yorgunluk yaşayan kanserli bireylerde yalnızlık, izolasyon, umutsuzluk ve depresyon gibi psikososyal sorunlar da daha sık görülmekte; arkadaşlarla vakit geçirme, kişilerarası ilişkileri sürdürme gibi sosyal aktiviteler etkilenmekte; dikkati bir konuya yoğunlaştırmada zorlanma ve unutkanlık gibi bilişsel sorunlar görülebilmektedir $[9,10]$. Kanser tanıs1 alan bireyler yorgunlukla baş etmede dinlenme ve/veya uyuma, enerji koruma tekniklerini kullanma, semptomu kabullenme veya varlığını inkar etme, egzersiz yapma, ilaç kullanma ve sosyal destek alma gibi baş etme yöntemlerini kullanabilmektedirler [12]. Belirtilen bu yöntemlere ek olarak kanser tanılı bireyler hastalık ve tedaviye bağlı gelişen yorgunluk ve diğer semptomların yönetiminde spiritüel baş etme yöntemlerine de başvurabilmektedirler [13].

Spiritüalite, bireyin kendisi ve diğer insanlarla olan ilişkilerini, evrendeki yerini, yaşamın anlamını bulma ve kabul etme çabası olarak tanımlanmıştır[14]. Varoluşsal ve dini boyutları bulunan spiritüelite kavramının varoluşsal boyutunu umut, kendine güven, iç huzur ve yaşamın anlamı gibi kavramlar oluştururken; dini boyutunu ise kutsal ve ebedi olana bağlilık duygusu oluşturmaktadır [14-16]. Literatürde spiritüel inanç ve uygulamaların kanser deneyimi boyunca ortaya çıkan fiziksel ve psikolojik sorunlarla baş etmeyi güçlendirdiği ve bireylerin spiritieliteyi bu sorunlarla baş etmede bir yöntem olarak kullandıkları bildirilmiştir [14,17-19]. Yapılan araştırmalar spiritüel iyilik hali yüksek olan kanserli bireylerin anksiyete düzeylerinin daha düşük ve umut duygularının daha güçlü olduğu, sağlıklı yaşam alışkanlıklarını daha iyi benimsedikleri ve yaşam kalitelerinin de daha iyi olduğunu destekler niteliktedir [20,21]. Buna benzer olarak spiritüel iyilik hali arttıkça kanserli bireylerin semptom sıkıntısının hafiflediğini rapor eden araştırmalar da bulunmaktadır [20,22,23].

Yorgunluk semptomu açısından bakıldığında, kanser ilişkili yorgunluk spiritüel iyilik hali penceresinden değerlendirilmemiș olup, yorgunluk şiddeti ile spiritüel iyilik hali arasındaki ilişki yalnızca bir çalışmada ele alınmıştır [24]. Kanser tanılı bireylerle çalışan hemşirelerin holistik yaklaşım kullanarak kanser ilișkili semptomları, özellikle yorgunluğu etkili şekilde yönetebilmeleri, hastaların konfor düzeylerini ve yaşam memnuniyetlerini arttırabilir [12]. Ayrıca, hemşirelerin kanserli bireylerde yorgunluğu etkileyebilecek durumları ve yorgunluğun bireyler üzerinde oluşturduğu fiziksel, psikolojik ve sosyal etkileri sistematik yolla ele alabilmesi, bireylerin spiritüel iyilik halinin gelişmesine de katk1 sağlayabilir [25]. Bu nedenle, kanserli bireylerde en sik görülen semptomlardan biri olan yorgunluğun algılanmasında spiritüel iyilik halinin etkileri incelenmelidir. $\mathrm{Bu}$ araştırma, kanserli bireylerde yorgunluk ve spiritüel iyilik hali arasındaki ilişkiyi araştırmak amacıyla yapılmıştır. Araştırma sonuçlarının onkoloji alanında çalışan hemşirelere yorgunluk semptomunu değerlendirirken bireylerin spiritüel iyilik hallerini de göz önünde bulundurmaları ve yorgunluk semptomunu etkileyebilecek spiritüel bakım gereksinimlerini karşılamada rehberlik edeceği düşünülmektedir. Ayrıca, bu araştırmadan elde edilen sonuçlarla kanser ilişkili yorgunluk yönetiminde bireylerin spiritüel bakım gereksinimlerinin ele alınabileceği müdahale araştırmalarına da katkı verilebileceği düşünülmektedir.

Araştırmanın amacı doğrultusunda oluşturulan araştırma soruları aşağıda belirtilmiştir: 
- Kanserli bireylerde yorgunluk şiddeti ve spiritüel iyilik hali nasıldır?

- Yorgunluk şiddeti ve spiritüel iyilik hali bireylerin tanıtıcı özelliklerine göre nasıl değişmektedir?

- Yorgunluk ve spiritüel iyilik hali puanları arasında bir ilişki var mıdır?

\section{Materyal ve Metot}

\subsection{Araştırmanın Tasarımı}

$\mathrm{Bu}$ araştırma, kemoterapi ve/veya radyoterapi alan bireylerde kanser ilişkili yorgunluk ve spiritüel iyilik hali arasındaki ilişkiyi incelemek amacıyla tanımlayıc1korelasyonel tasarımla yapılmıştır.

\subsection{Arastırmanın Yeri ve Zamanı}

$\mathrm{Bu}$ araştırma, bir kamu üniversitesi hastanesinin gündüz tedavi ünitesi ve radyasyon onkolojisi polikliniğinde 10 Haziran- 25 Temmuz 2019 tarihleri arasinda yürütülmüştür.

\subsection{Araştırmanın Evreni ve Örneklemi}

Araştırmanın evrenini bir kamu üniversitesi hastanesinin gündüz tedavi ünitesi ve radyasyon onkoloji polikliniği'nde ayaktan kemoterapi ve radyoterapi alan kanserli bireyler oluşturmuştur. Araştırmaya 18 yaş üzerinde olan, iletişime engel olacak fiziksel ve/veya mental sağlık sorunu bulunmayan, kanser hastası olduğunu bilen ve araștırmaya katılmaya gönüllü olan bireyler dahil edilmiştir. İletişime engel oluşturacak fiziksel ve/veya mental sağlık sorunu bulunan, tanısını bilmeyen ve araştırmaya katılmayı kabul etmeyen bireyler araştırma kapsamına alınmamıştır. Araştırmada amaçlı örnekleme yöntemi kullanılmıș ve belirtilen tarih aralığında gündüz tedavi ünitesinde ve radyasyon onkolojisi polikliniğinde tedavi alan ve araştırma kriterlerine uyan tüm bireyler araștırmaya dahil edilmișlerdir. Veri toplama sürecinde 187 hastaya ulaşılmış; 1 hasta tanısını bilmediği, 3 hasta Türkçe konuşamadığı ve 54 hasta araştırmaya katılmayı kabul etmediği için araștırmaya dahil edilememiștir. $\mathrm{Bu}$ nedenle araştırma 129 kişiyle tamamlanmıştır. Araştırmanın gücü, elde edilen veriler üzerinden posthoc power analiz yapılarak G. Power 3.1. programı ile belirlenmiștir. Kanserli bireylerin FACIT yorgunluk ölçeği puanları ile FACIT-Sp ölçeği puanları arasındaki ilişki Spearman korelasyon testi kullanılarak, alfa değeri:0,05, etki büyüklüğü:0,5 olarak temel alındığında araștırmanın gücü 0,97 olarak hesaplanmıştır.

\subsection{Veri Toplama Araçlarl}

\subsubsection{Kişisel Bilgi Formu}

Kişisel bilgi formu, araştırmaya dahil edilen bireylerin bazı sosyo-demografik özellikleri ile hastalık ve tedavi sürecine ilişkin özelliklerini tanımlamak amacıyla araştırmacılar tarafından oluşturulmuştur. $\mathrm{Bu}$ formda sosyo-demografik özelliklere (yaş, cinsiyet, medeni durum, eğitim durumu, gelir durumu) ve hastalık ve tedavi süreci özelliklerine ilişkin (kanser türü, kanser evresi, güncel tedavi protokolü, tanı anından beri geçen süre, kronik hastalık varlığı, hemoglobin değeri) toplam 11 soru bulunmaktadir[22-24].

\subsubsection{Kronik Hastalı Tedavisi Fonksiyonel} Değerlendirmesi Yorgunluk (FACIT-F) Ölçeği
FACIT-F Ölçeği, son bir hafta içerisindeki yorgunluğu subjektif olarak değerlendiren ve 13 ifadeden oluşan bir ölçüm aracıdır. Ölçek, " $0=$ hiç, $1=$ çok az, 2=biraz, $3=$ oldukça ve $4=$ çok fazla" olmak üzere beşli likert derecelendirmesine sahiptir. Ölçeğin 11 maddesi (1-6, 913) ters ifade içermektedir. Ölçeğin 7 ve 8. maddeleri ise düz olarak hesaplanmaktadır. Ölçekten alınabilecek puanlar 0-52 arasında değişmektedir. Ölçek toplam puanının yüksek olması, yorgunluk şiddetinin düşük olduğunu ifade etmektedir. Ölçekten alınan puanın 30 ve altında olması durumunda algılanan yorgunluğun klinik açıdan şiddetli olduğu bildirilmektedir [26]. Ölçeğin Türkçe geçerlilik ve güvenilirlik analizi Çınar ve Yava tarafindan yapılmış ve Cronbach alfa katsayısı 0,98 olarak bulunmuştur [27]. Bu araştırmada FACIT-F Ölçeği'ne ilişkin Cronbach alfa katsayısı, 0,905 olarak hesaplanmıştır.

2.4.3. Kronik Hastallk Tedavisi Fonksiyonel Değerlendirmesi Spirituel İyilik Hali (FACIT-Sp) Ölçeği FACIT-Sp, kronik ve yaşamı tehdit eden bir hastalığ 1 olan bireylerin spiritüel iyilik hallerini değerlendirmek amacıyla, geliştirilmiş bir ölçüm aracıdır [28]. Ölçek, " 0 =hiç, $1=$ çok az, $2=$ biraz, $3=$ oldukça ve $4=$ çok fazla" olmak üzere beşli likert derecelendirmesine sahip 12 maddeden oluşmaktadır. Ölçeğin "Anlam" alt boyutu (2., 3., 5. ve 8. maddeler), "Barıs" alt boyutu (1., 4., 6. ve 7. maddeler) ve "İnanç" alt boyutu (9., 10., 11. ve 12. maddeler) olmak üzere toplam üç alt boyutu bulunmaktadır. FACIT-Sp Ölçeği'nde bireylerin son 7 günü göz önünde bulundurmaları ve ölçek maddelerini buna göre cevaplamaları beklenmektedir. Ölçekte negatif anlam taşıyan 4 . ve 8 . sorular için ters puanlama yapılmaktadır. Ölçekten alınabilecek toplam puan 0-48 puan arasında değişmekte, ölçekten alınan puanların yüksek olması, bireyin spiritüel iyilik düzeyinin arttığını, alınan puanların düşük olması ise bireyin spiritüel iyilik düzeyinin azaldığını göstermektedir. FACIT-Sp Ölçeği'nin Türk kültürüne uyarlanması Aktürk ve ark. tarafindan yapılmış ve Cronbach alfa katsayısı "İnanç" alt boyutu için 0,93, "Anlam" alt boyutu için 0,78, "Barış" alt boyutu için 0,81 ve ölçeğin geneli için 0,87 olarak hesaplanmıștır [29]. Bu araştırmada Cronbach alfa katsayısı "İnanç" alt boyutu için 0,698, "Anlam" alt boyutu için 0,773, "Barış" alt boyutu için 0,800 ve ölçeğin geneli için 0,834 olarak hesaplanmıştır

\subsection{Verilerin Toplanmasi}

Araştırmaya dahil edilme kriterlerini karşılayan bireylerin sözlü ve yazılı onamları alındıktan sonra Kişisel Bilgi Formu, ardından FACIT yorgunluk ve FACIT-Sp ölçekleri araştırmacılar tarafından yüz-yüze görüşme tekniği kullanılarak doldurulmuş ve her bir hasta için veri toplama süreci yaklaşık 10-15 dakika sürmüştür.

\subsection{Verilerin Analizi}

Araștırmadan elde edilen veriler IBM SPSS istatistik programının 23.0 versiyonu ile analiz edilmiştir. Verilerin normal dağılıma uygunluğunu değerlendirmede Kolmogrov Smirnov testi kullanılmıştır. Normal dağılım gösteren veriler için ortalama ve standart sapma, normal dağılım göstermeyen 
veriler için ortanca, 25. ve 75. yüzdelik dilimleri, minimum ve maksimum değerleri kullanılmıştır. Kategorik veriler için ise sayı ve yüzde hesaplamalarından yararlanılmıştır. Yorgunluk ve spiritüel iyilik hali puanlarında örneklemin tanıtıcı özelliklere göre istatistiksel fark olup olmadığını değerledirmek için Mann-Whitney U ve Kruskal Wallis testleri kullanılmıştır. Farkı yaratan grubun belirlenmesi için ileri post-hoc Bonferoni düzeltmeli Mann-Whitney $\mathrm{U}$ testinden yararlanılmıştır. Yorgunluk ve spiritüel iyilik hali ölçeği toplam puanları arasındaki ilişkiyi incelemek için Spearman Korelasyon katsayısı kullanılmıştır. Tüm istatistiksel hesaplamalarda istatistiksel anlamlılık için $\mathrm{p}<0,05$ değeri temel alınmıştır.

\subsection{Araştırmanın Etik Yönü}

Araştırmanın uygulanabilmesi için Hacettepe Üniversitesi Girişimsel Olmayan Klinik Araştırmalar Etik Kurulu'ndan etik kurul izni (Karar no: 2019/13-03) ve araştırmanın yürütüleceği kurumdan kurum izini alınmıştır. Araştırmaya katılan tüm bireylerin sözlü ve yazılı onamları alınmıştır.

\section{Bulgular \\ 3.1. Kanserli Bireylerin Tanıtıcı Özellikleri}

Araștırmaya dahil edilen bireylerin yaș ortalaması $56,64 \pm 12,28$ yıl olup, yarısından fazlasını 56 yaş ve üzeri bireyler $(\% 57,4)$ ve kadınlar $(\% 54,3)$ oluşturmuştur. Araştırma örnekleminin büyük çoğunluğu evli $(\% 82,2)$; \%37,2'si ilköğretim mezunu olup; \%67,7'si gelir durumunu "gelir gidere eşit" olarak tanımlamıştır. Araştırmaya dahil edilen bireylerin kanser tanı süre ortalamasının $12,94 \pm 3,06$ ay olduğu ve bireylerin \%69'unun 1-6 ay önce tanı aldığı belirlenmiştir. Araştırmadaki bireylerin \%31,8'inin gastrointestinal sistem, \%22,5'inin akciğer kanseri, \%14,7'sinin jinekolojik kanser ve \%12,4'ünün meme kanseri olduğu görülmüştür

Tablo 1. Tanımlayıcı Özelliklere Göre Ölçek Puanlarının Dağılımı (N=129)

\begin{tabular}{|c|c|c|c|c|c|c|c|c|}
\hline & & & FACIT-F & \multirow[b]{2}{*}{$\begin{array}{c}\text { Test } \\
\text { değeri }\end{array}$} & \multirow[b]{2}{*}{$\mathbf{p}$} & FACIT-Sp & \multirow[b]{2}{*}{$\begin{array}{c}\text { Test } \\
\text { değeri }\end{array}$} & \multirow[b]{2}{*}{$\mathbf{p}$} \\
\hline Yaş $^{\mathrm{a}}(56,64 \pm 12,28)$ & $\mathbf{N}$ & $\%$ & $\begin{array}{c}\text { Medyan } \\
\text { (25. ve } 75 . \\
\text { Yüzdelik) } \\
\end{array}$ & & & $\begin{array}{l}\text { Medyan } \\
\text { (25. ve } 75 . \\
\text { Yüzdelik) } \\
\end{array}$ & & \\
\hline $18-55$ & 55 & 42,6 & $36,0(29,0 ; 43,0)$ & \multirow{2}{*}{${ }^{\mathrm{c}} 1,916$} & \multirow{2}{*}{0,569} & $34,0(30,0 ; 38,0)$ & \multirow{2}{*}{${ }^{\mathrm{c}} 1,950$} & \multirow{2}{*}{0,684} \\
\hline $56-+$ & 74 & 57,4 & $32,0(24,0 ; 45,2)$ & & & $34,0(24,0 ; 39,2)$ & & \\
\hline \multicolumn{9}{|l|}{ Cinsiyet } \\
\hline Kadın & 70 & 54,3 & $32,0(24,0 ; 37,5)$ & \multirow{2}{*}{${ }^{\mathrm{c}} 1,515$} & \multirow{2}{*}{0,009} & $34,0(29,0 ; 38,0)$ & \multirow{2}{*}{${ }^{\mathrm{c}} 1,892$} & \multirow{2}{*}{0,412} \\
\hline Erkek & 59 & 45,7 & $28,0(37,0 ; 46,0)$ & & & $35,0(30,0 ; 40,0)$ & & \\
\hline \multicolumn{9}{|l|}{ Medeni durum } \\
\hline Evli & 106 & 82,2 & $33,0(24,7 ; 44,0)$ & \multirow{2}{*}{${ }^{\mathrm{c}} 1,125$} & \multirow{2}{*}{0,563} & $34,5(30,0 ; 39,0)$ & \multirow{2}{*}{ c998,5 } & \multirow{2}{*}{0,174} \\
\hline Bekar & 23 & 17,8 & $35,0(32,0 ; 43,0)$ & & & $32,0(28,0 ; 37,0)$ & & \\
\hline \multicolumn{9}{|l|}{ Eğitim durumu } \\
\hline İlköğretim & 48 & 37,2 & $30,0(24,2 ; 39,7)$ & \multirow{3}{*}{$\mathrm{d} 4,773$} & \multirow{3}{*}{0,092} & $32,5(29,0 ; 37,7)$ & \multirow{3}{*}{${ }^{\mathrm{d}} 1,489$} & \multirow{3}{*}{0,475} \\
\hline Lise & 36 & 27,9 & $35,0(24,2 ; 44,0)$ & & & $36,5(30,0 ; 40,0)$ & & \\
\hline Üniversite & 45 & 34,9 & $37,0(28,0 ; 46,5)$ & & & $34,0(30,0 ; 38,5)$ & & \\
\hline \multicolumn{9}{|l|}{ Gelir durumu } \\
\hline Gelir-giderden az & 32 & 24,8 & $29,5(22,2 ; 41,0)$ & \multirow{3}{*}{ d3,601 } & & $32,5(25,0 ; 38,5)$ & & \\
\hline Gelir-gidere eşit & 86 & 66,7 & $36,0(27,7 ; 44,0)$ & & 0,165 & $34,5(30,0 ; 39,0)$ & ${ }^{d} 2,307$ & 0,314 \\
\hline Gelir giderden fazla & 11 & 8,5 & $35,0(24,0 ; 46,0)$ & & & $30,0(23,0 ; 42,0)$ & & \\
\hline Tanı süresi (ay) ${ }^{a}(12$ & $30,60)$ & & & & & & & \\
\hline $1-6$ ay & 89 & 69,0 & $36,0(25,0 ; 45,0)$ & & & $35,0(30,0 ; 39,0)$ & & \\
\hline$\geq 7$ ay & 40 & 31,0 & $31,5(23,5 ; 47,0)$ &, 436 & 0,079 & $32,5(25,5 ; 37,0)$ & 1,412 & 0,060 \\
\hline Kanser türü & & & & & & & & \\
\hline GİS & 41 & 31,8 & $36,0(25,5 ; 46,0)$ & & & $33,0(29,0 ; 38,0)$ & & \\
\hline Akciğer & 29 & 22,5 & $37,0(26,0 ; 47,0)$ & & & $35,0(30,0 ; 40,5)$ & & \\
\hline Jinekolojik & 19 & 14,7 & $30,0(15,0 ; 36,0)$ & d8,294 & 0,081 & $31,0(28,0 ; 38,0)$ & ${ }^{d} 2,685$ & 0,612 \\
\hline Meme & 16 & 12,4 & $33,5(26,2 ; 40,0)$ & & & $28,7(35,0 ; 39,0)$ & & \\
\hline${ }^{\mathrm{b}}$ Diğger & 24 & 18,6 & $32,0(24,0 ; 43,7)$ & & & $35,0(31,2 ; 39,7)$ & & \\
\hline Kanser evresi & & & & & & & & \\
\hline Evre I & 13 & 10,1 & $37,0(30,5 ; 46,0)$ & & & $34,0(28,5 ; 37,5)$ & & \\
\hline Evre II & 35 & 27,1 & $37,0(32,0 ; 45,0)$ & & & $37,0(31,0 ; 41,0)$ & & \\
\hline Evre III & 42 & 32,6 & $33,5(25,7 ; 45,2)$ & 14,089 & $0,003^{*}$ & $33,0(29,0 ; 37,2)$ & "5,324 & 0,150 \\
\hline *Evre IV & 39 & 30,2 & $28,0(21,0 ; 37,0)$ & & & $33,0(28,0 ; 37,0)$ & & \\
\hline Uygulanan tedavi & & & & & & & & \\
\hline Kemoterapi & 99 & 76,7 & $32,0(24,0 ; 43,0)$ & & & $34,0(29,0 ; 38,0)$ & & \\
\hline Radyoterapi & 10 & 7,8 & $36,5(29,2 ; 42,0)$ & d5,227 & 0,073 & $32,5(26,2 ; 35,2)$ & ${ }^{\mathrm{d}} 1,683$ & 0,431 \\
\hline Kombine tedavi & 20 & 15,5 & $40,0(32,0 ; 48,0)$ & & & $35,0(30,0 ; 41,0)$ & & \\
\hline Kronik hastalık var & & & & & & & & \\
\hline Yok & 69 & 53,5 & $37,0(27,0 ; 46,0)$ & & & $34,0(30,0 ; 39,5)$ & & \\
\hline Var & 60 & 46,5 & $31,5(23,2 ; 42,7)$ & ${ }^{c} 1,618$ & 0,032 & $34,0(29,0 ; 38,0)$ & ${ }^{c} 1,862$ & 0,325 \\
\hline
\end{tabular}

aOrtalama \pm Standart sapma, bProstat, larenks, lenfoma, mezotelyoma, testis, yumuşak doku tümörü cMann Whitney U testi kullanılmıştır. dKruskal Wallis testi kullanılmıștır. *Bonferoni düzeltmeli Mann-Whitney U testi kullanılmıștır 
Araştırmaya dahil edilen bireylerin \%32,6’sının kanser evresinin evre-3 olduğu belirlenmiştir. Araştırma sırasında bireylerin büyük çoğunluğunun $(\% 76,7)$ kemoterapi aldığ1 gözlenmiştir. Bireyler, komorbid hastalık varlığı açısından incelendiğinde, \%46,5'inin en az bir kronik hastalığ 1 olduğu bulunmuştur (Tablo 1).

Tabloda belirtilmemekle birlikte bireylerin hemoglobin değeri ortalamasının $11,85 \pm 1,50 \mathrm{~g} / \mathrm{dl}$ olduğu hesaplanmıştır.

\subsection{FACIT-F ve FACIT-Sp Puanlarının Dağılımı}

Her iki ölçekten alınan puan ortancaları incelendiğinde hem FACIT yorgunluk ölçeği hem de FACIT-Sp ölçeği puan ortancalarının 34,0 olduğu belirlenmiştir. FACIT yorgunluk ölçeğinden alınan puanlar 7-52 arasında dağılım gösterirken; FACIT-Sp ölçeğinden alınan puanlar 10-48 arasında dağılmıştır (Tablo 2). FACIT-Sp ölçeği alt boyut puan ortancaları: anlam alt boyutu için 13,0; barış ve inanç alt boyutları için 11,0 olarak hesaplanmıştır (Tablo 2). Tabloda belirtilmemekle birlikte, araştırma örnekleminin \%65, 1 'inde FACIT yorgunluk ölçeği toplam puanının 30’un üstünde olduğu ve bu bireylerin yorgunluk düzeylerinin şiddetli olmadığ 1 belirlenmiştir.

Bireylerin tanıtıcı özelliklerine göre ölçek puanlarında anlamlı bir farklılık olup olmadığı değerlendirildiğinde; yaş, medeni durum, eğitim

durumu, kanser türü, tanı süresi ve uygulanan tedavi türüne göre yorgunluk şiddeti ve spiritüel iyilik halinde istatistiksel olarak anlamlı bir farklılık bulunmamıştır ( $p>0,05)$. Cinsiyet değişkeni açısından incelendiğinde, yorgunluk şiddetinin erkeklerde ve kronik hastalığ 1 olan bireylerde anlamlı düzeyde yüksek olduğu belirlenmiştir $(\mathrm{p}<0,05)$. Buna ek olarak, evre IV kanser tanisı olan bireylerin algıladıkları yorgunluk şiddetinin diğer kanser evrelerine göre anlamlı düzeyde daha yüksek olduğu bulunmuştur $(p<0,05)$. Cinsiyet, kronik hastalık varlı̆̆ ve kanser evresi değişkenlerine göre FACIT-Sp ölçeği puanlarındaki değişim incelendiğinde, bu değişkenler açısından ölçek puanlarında anlamlı bir farkın olmadığ görülmüş̧ür (Tablo 1; p>0,05).

Tablo 2. FACIT-F ve FACIT-Sp Ölçeklerinin Puan Dağılımı $(\mathrm{N}=129)$

\begin{tabular}{lllll}
\hline Ölçek & Median & 25. yüzdelik & 75. yüzdelik & Min-Maks \\
\hline FACIT Yorgunluk & 34,0 & 25,0 & 44,0 & $7,0-52,0$ \\
\hline FACIT-Sp & 34,0 & 29,0 & 39,0 & $10,0-48,0$ \\
\hline Anlam & 13,0 & 11,0 & 15,0 & $4,0-16,0$ \\
Barış & 11,0 & 8,0 & 13,0 & $0,0-16,0$ \\
İnanç & 11,0 & 9,0 & 14,0 & $2,0-16,0$ \\
\hline
\end{tabular}

\section{FACIT-F ve FACIT-Sp Ölçek Puanları Arasındaki Korelasyon}

Yorgunluk şiddeti ve spiritüel iyilik hali arasındaki ilişki incelendiğinde, FACIT yorgunluk ölçeği ile FACIT-Sp ölçeğinden alınan puanlar arasında pozitif yönde zayıf bir korelasyon bulunmuş ve spiritüel iyilik hali puanları arttıkça yorgunluk ölçeğinden alınan puanların da artış gösterdiği belirlenmiştir $(p<0,001)$. Ayrıca, FACIT yorgunluk ölçeği ile FACIT-Sp ölçeğinin "anlam” ve "barış" alt boyut puanları arasında da pozitif yönde zayıf bir korelasyon bulunmuştır (Tablo3; $\mathrm{p}<0,001$ ). İki ölçek puanları arasındaki korelasyon grafiği Şekil 1'de gösterilmiştir.

Tablo 3. FACIT-F ve FACIT-Sp Ölçekleri Arasındaki Korelasyon $(\mathrm{N}=129)$

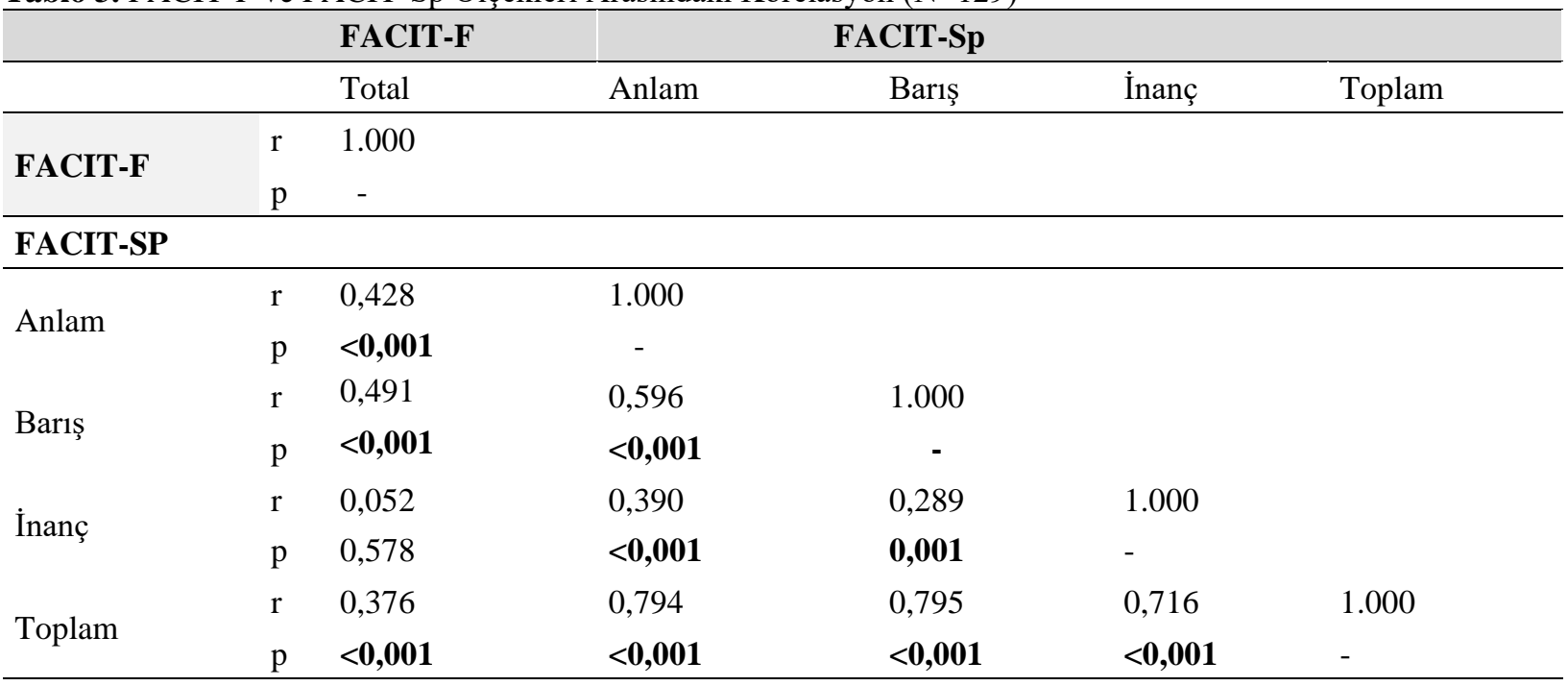




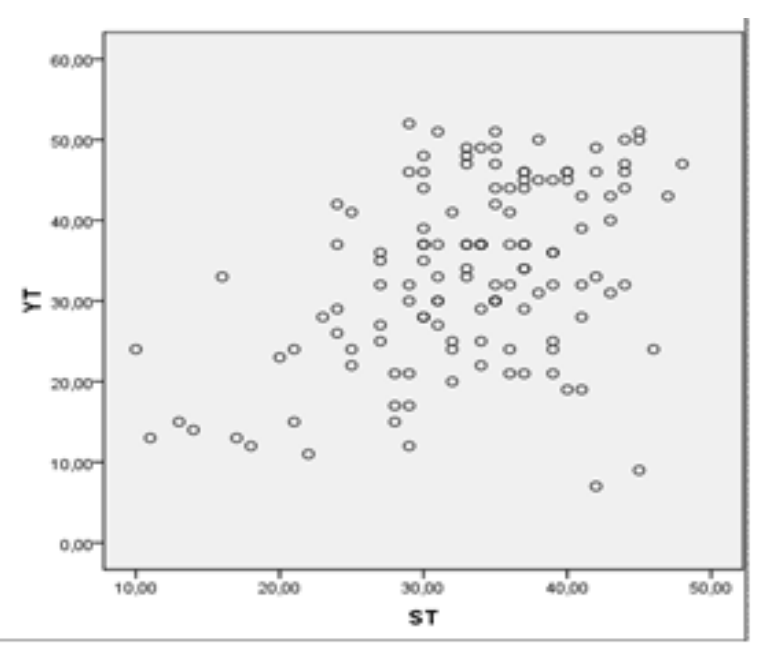

Şekil 1. Yorgunluk şiddeti ile spiritüel iyilik hali arasındaki iliş̧ki

*ST: Spiritüel İyilik Hali Ölçeği Toplam Puanı

**YT: Yorgunluk Ölçeği Toplam Puanı

\section{Tartışma}

Literatürde kanserli bireylerin sıklıkla yakındıkları fiziksel semptomlar arasında yer alan yorgunluğun değerlendirilmesi, yorgunluk yönetiminde bireylerin desteklenmesi ve yorgunlukla baş etmede bireysel baş etme yöntemlerinin geliştirilmesi onkoloji hemşireliği açısından önemle ele alınması gereken bir konudur. $\mathrm{Bu}$ araştırmada, farklı kanser tanılarına sahip, erken veya ileri evrede olan ve farklı tedavi süreçlerinden geçen bireylerin yorgunluk şiddetleri belirlenmiş, yorgunluğu anlamlandırma ve yönetmede bireyler üzerinde olumlu veya olumsuz etki gösterebilen spiritüel iyilik hali de eş zamanlı olarak değerlendirilmiştir. Araştırma sonucunda hastaların spiritüel iyilik hali arttıkça yorgunluk şiddetinin azaldığı bulunmuştur.

$\mathrm{Bu}$ araştırmada yorgunluk şiddeti puan ortancası 34 olarak belirlenmiştir. Literatürde farklı kanser türü ve evrelerine sahip bireylerle yürütülen başka bir çalışmada yorgunluk şiddeti ortalamasının $36,1 \pm 12,1$ olduğu rapor edilmiştir [30]. Courtier ve ark.'nın [31] radyoterapi alan meme kanserli bireylerde yorgunluğu değerlendirdikleri başka bir çalışmada, yorgunluk puanı ortancası 44 olarak bildirilmiştir. Yukarıda sonuçları bildirilen her iki araştırmada da hastaların yorgunluk şiddetleri FACIT yorgunluk ölçeği ile değerlendirilmiş, hastaların algıladıkları yorgunluk şiddetinin bu araştırma bulguları ile benzerlik gösterdiği ortaya çıkmıştır. Literatürde kanser tanılı bireylerde yorgunluğun cinsiyet, yaş, kanser türü, kanser evresi, komorbid hastalıklar ve tedavi seçeneklerinden etkilenebileceği bildirilmiştir [32-34]. $\mathrm{Bu}$ araştırmada bireylerin tanımlayıcı özelliklerine göre yorgunluk şiddetindeki farklılık incelendiğinde erkek, hastalığı ileri evrede olan ve komorbid hastalığı bulunan bireylerin daha şiddetli yorgunluk yaşadıkları ortaya çıkmıştır. Yaş ve kanser türü değişkenleri açısından değerlendirildiğinde ise algınan yorgunluk şiddetinde herhangi bir fark bulunmamıștır. Lewis ve ark.'nın [24] 200 kanserli bireyle yorgunluğu değerlendirdikleri bir çalışmada, bireylerin kanser türü ve aldıkları tedavi türünün bu araştırmaya benzer şekilde yorgunluk şiddeti üzerinde anlamlı bir fark oluşturmadığı bildirilmiştir. Aynı araştırmada bu araştırma bulgularından faklı olarak cinsiyete göre yorgunluk şiddetinde anlamlı bir farklılık olmadığı rapor edilmiştir [24]. Literatürde bu araştırma bulgularından farklı olarak, yaş ve kanser türünün yorgunluk şiddetini etkilediğini bildiren araştırmalar da bulunmaktadır $[34,35]$. Bu araştırma ve önceki araştırma bulguları arasındaki farklılıkların, örneklem özelliklerinden, yorgunluğun subjektif ve çok boyutlu bir semptom olmasından kaynaklanabileceği öngörülmüştür.

$\mathrm{Bu}$ araştırmada incelenen diğer bir parametre ise kanserli bireylerin spiritüel iyilik halleridir. Araştıma kapsamındaki bireylerde spiritüel iyilik hali puan ortancasının 34 olduğu ortaya çıkmıştır. Bai ve ark.'nın [20] Amerika Birleşik Devletleri'nde 52 ileri evre kanser tanılı bireyde spiritüel iyilik halini inceledikleri bir araştırmada; FACIT-SP ölçeği puan ortalaması 36,37 olarak bildirilmiştir [20]. Kandasamy ve ark.'nın[36] Hindistan'da ileri evre kanserli bireylerde gerçekleştirdikleri başka bir araştırmada da bireylerin spiritüel iyilik hali puan ortalaması 24,48 olarak daha düşük düzeyde rapor edilmiştir. Leak ve ark.'nın [22] Afrika kökenli olup Amerika'da yaşayan meme kanserli bireylerde spiritüel iyilik halini inceledikleri başka bir araştırmada da bireylerin spiritüel iyilik hallerinin yüksek olduğu bildirilmiştir. Bu araştırma bulgularının Bai ve ark.[20] ile Leak ve ark.'nın [22] araştırma sonuçları ile tutarlı olduğu; Kandasamy ve ark.'nın [36] sonuçlarını doğrulamadığı dikkat çekicidir. Yukarıda belirtilen araştırmalar örneklem özellikleri açısından incelendiğinde; Bai ve ark.'nın [20] kanser evresi, yaş ve cinsiyet açısından araştırma örneklemimize benzer kanserli bireylerle çalıştığ ise araştırmalarını sadece 50 ileri evre hospis hastası ile yürüttükleri görülmüştür. Tüm bu bulgular ele alındığında; araştırma sonuçlarındaki farklılıkların bireylerin yaşadıkları kültürel ortamlar, değer ve inançları, hastalıklarının doğası ve kullandıkları baş etme yöntemleri ile ilgili olabileceği düşünülmüştür.

$\mathrm{Bu}$ araştırmada literatüre katkı sağlayan ve altı çizilmesi gereken bir diğer önemli bulgu ise; kanserli bireylerin yorgunluk şiddeti ile spiritüel iyilik hali arasındaki ilişkinin belirlenmesidir. Araştırmada bireylerin yorgunluk şiddetleri ile spiritüel iyilik halleri arasında pozitif yönde zayıf düzeyde anlamlı bir korelasyon 
ortaya çıkmıştır. Kandasamy ve ark.'nın ileri evre kanserli bireylerde anksiyete, depresyon, semptom sıkıntısı, yaşam kalitesi ve spiritüel iyilik hali arasındaki ilişikiyi değerlendirdikleri araştırmada da bu araştırmaya benzer şekilde yorgunluk şiddeti ile spiritüel iyilik hali arasında zayıf düzeyde anlamlı bir ilişki olduğu bildirilmiştir [36]. Rabow ve Knish'in ayaktan tedavi edilen kanserli bireylerde spiritüel iyilik halini inceledikleri bir diğer çalışmada, bireylerin yorgunluk düzeyi arttıkça spiritüel iyilik hallerinin azaldığ 1 rapor edilmiştir [23]. Lewis ve ark.'nın farklı evre kanser tanısı olan bireylerle yürütükleri bir çalışmada da bireylerin yorgunluk şiddeti ile spiritüel iyilik halleri arasında negatif yönde zayıf düzeyde anlamlı ilişki ortaya konmuştur [24]. Bu araştırma ve önceki araştırma bulguları bütüncül olarak yorumlandığında, bireylerin yorgunluk şiddeti arttığında spiritüel iyilik halinin de daha düşük olduğu görülmüştür.

\subsection{Araștırmanın Sinırlılıkları}

Bu araştırmada kanser türü, evresi, alınan tedavi türü, yaş ve cinsiyet gibi değiş̧kenler gözetilmeksizin karma bir örneklemde yorgunluk ve spiritüel iyilik hali arasındaki ilişki incelenmiştir. $\mathrm{Bu}$ nedenle araştırma sonuçlarının tüm kanserli bireylere genellenemeyeceği göz önünde bulundurulmalıdır. Ayrıca araştırmada bireyler kemoterapi veya radyoterapi seanslarının sayıs gözetilmeksizin bir defaya mahsus değerlendirilmiş, prospektif bir izlem yapılmamıştır.

\section{Sonuc}

$\mathrm{Bu}$ araștırmada bireylerin algıladıkları yorgunluğun genel olarak çok şiddetli olmadığı ve cinsiyet, kanser evresi ve kansere eşlik eden kronik hastalıklardan anlamlı düzeyde etkilendiği sonucuna ulaşılmış, yorgunluk şiddeti azaldıkça spiritüel iyilik halinin arttığı ortaya çıkmıştır. Araştırma sonuçlarından hareketle; onkoloji hemşirelerinin kanser ilişkili yorgunluğu değerlendirirken bireylerin spiritüel iyilik halleri ve spiritüel bakım gereksinimlerini de göz önünde bulundurmaları ve bu gereksinimlere yönelik uygun hemşirelik girişimlerini planlamaları, spesifik kanser türü ve evrelerini de ele alan ileri prospektif araştırmaların yapılması önerilmiştir.

\section{Referanslar}

1. Weis, J, Cancer-related fatigue: prevalence, assessment and treatment strategies. Expert Review of Pharmacoeconomics \& Outcomes Research, 2011, 11(4), 441-6.

2. Karakoç, T, Kanser hastalarında yorgunluk ve hemşirelik bakımı, Firat Sağlık Hizmetleri Dergisi, 2008, 3(8), 99-118.

3. Can, G, Enç, N, Akkaya, S, Onkoloji hemşireliğinde kanıta dayalı semptom yönetimi, Konsensus, 2007, 7, 64-6.

4. Sherman, DW, Palliative care nursing: Quality care to the end of life: Springer Publishing Company, 2010.

5. Wang, XS, Zhao, F, Fisch, M, O'Mara, AM, Cella, D, Mendoza, TR, Cleeland, CS, Prevalence and characteristics of moderate to severe fatigue: a multicenter study in cancer patients and survivors, Cancer 2014, 120(3), 425-32.

6. Aydın Bektaş H, Akdemir, N, Kanserli bireylerde fonksiyonel durumun Oönemi, Atatürk Üniversitesi Hemșirelik Yüksekokulu Dergisi, 2009, 12(3), 54-60.

7. Karakoç, T, Kanser hastalarında yorgunluk ve hemirelik bakımı, Fırat Sağlık Hizmetleri Dergisi, 2008, 3(8), 99-118.
8. Yavuzșen, T, Kömürcü, S. Kanser hastalarında halsizlik semptomunun değerlendirilmesi ve birlikte görülen klinik problemler. Gülhane Tip Dergisi, 2008, 50 (2),141-46.

9. Curt, GA, editor Impact of fatigue on quality of life in oncology patients. Seminars in Hematology, 2000, Elsevier.

10. Curt, GA, Breitbart, W, Cella, D, Groopman, JE, Horning, SJ, Itri, LM et al, Impact of cancer-related fatigue on the lives of patients: new findings from the Fatigue Coalition, The Oncologist, 2000,5(5), 35360 .

11. Charalambous, A, Kouta, C, Cancer related fatigue and quality of life in patients with advanced prostate cancer undergoing chemotherapy, BioMed Research International, 2016.

12. Mitchell, SA, Cancer-related fatigue, Cancer Nursing: Principles and Practice, 2011, 772-91.

13. Visser, A, Garssen, B, Vingerhoets, A, Spirituality and well-being in cancer patients: a review, Psycho-Oncology: Journal of the Psychlogical, Social and Behavioral Dimensions of Cancer, 2010, 19(6), 565-72.

14. Bulkley, J, McMullen, CK, Hornbrook, MC, Grant, M, Altschuler, A Wendel, CS, et al. Spiritual well-being in long-term colorectal cancer survivors with ostomies, Psycho-Oncology: Journal of the Psychlogical, Social and Behavioral Dimensions of Cancer, 2013, 22(11), 2513-21.

15. Cotton, SP, Levine, EG, Fitzpatrick, CM, Dold, KH, Targ, E, Exploring the relationships among spiritual well-being, quality of life, and psychological adjustment in women with breast cancer. Psycho-Oncology: Journal of the Psychlogical, Social and Behavioral Dimensions of Cancer, 1999, 8(5), 429-38.

16. Vincensi, BB, Interconnections: Spirituality, spiritual care, and patient-centered care, Asian Pacific Journal of Oncology Nursing, 2019, 6(2), 104

17. Baetz, M, Bowen, R. Chronic pain and fatigue: Associations with religion and spirituality, Pain Research and Management, 2008, 13(5), 383-8

18. Meraviglia, M, editor Effects of spirituality in breast cancer survivors. Oncology Nursing Forum, 2006, 33(1), E1-E7.

19. Sousa, FFdPR, Freitas, SMFdM, Farias, AGdS, Cunha, MdCdS, Araújo, MFMd, Veras ,VS, Religious/spiritual coping by people with cancer undergoing chemotherapy: Integrative literature review, SMAD, Revista Eletrônica Saúde Mental Alcool e Drogas, 2017,13(1), 45-51.

20. Bai, M, Lazenby, M, Jeon, S, Dixon, J, McCorkle, R, Exploring the relationship between spiritual well-being and quality of life among patients newly diagnosed with advanced cancer, Palliative \& Supportive Care, 2015, 13(4), 927-35.

21. Whitford, HS, Olver, IN, Peterson, MJ, Spirituality as a core domain in the assessment of quality of life in oncology, Psycho-Oncology: Journal of the Psychlogical, Social and Behavioral Dimensions of Cancer, 2008, 17(11), 1121-8.

22. Leak, A, Hu J, King, CR, Symptom distress, spirituality, and quality of life in African American breast cancer survivors, Cancer Nursing, 2008, 31(1), E15-E21.

23. Rabow, MW, Knish, SJ, Spiritual well-being among outpatients with cancer receiving concurrent oncologic and palliative care, Supportive Care in Cancer, 2015, 23(4), 919-23.

24. Lewis, S, Salins, N, Rao, MR, Kadam, A, Spiritual well-being and its influence on fatigue in patients undergoing active cancer directed treatment: A correlational study, Journal of Cancer Research and Therapeutics, 2014, 10(3), 676-80.

25. Çetinkaya, B, Altundağ, S, Azak, A, Spiritüel bakım ve hemşirelik. Adnan Menderes Üniversitesi Tip Fakültesi Dergisi, 2007, 8(1), 47 50 .

26. Tennant, K, Assessment of fatigue in older adults: the FACIT fatigue scale (version 4). Supportive Care in Cancer, 2015, 23(5), 1355-64.

27. Cinar, D, Yava, A, Validity and reliability of functional assessment of chronic illness treatment-fatigue scale in Turkish patients with type 2 diabetes, Endocrinologia Diabetes y Nutrition, 2018, 65(7), 409-17.

28. Peterman, AH, Fitchett,, G, Brady, MJ, Hernandez, L, Cella, D, Measuring spiritual well-being in people with cancer: the functional assessment of chronic illness therapy-Spiritual well-being scale (FACIT-Sp), Annals of Behavioral Medicine, 2002, 24(1), 49-58.

29. Aktürk, Ü, Erci,, B, Araz M, Functional evaluation of treatment of chronic disease: Validity and reliability of the Turkish version of the spiritual well-being scale, Palliative \& Supportive Care, 2017, 15(6), 684-92. 
30. Butt, Z, Lai, J-s, Rao, D, Heinemann, AW, Bill, A, Cella, D, Measurement of fatigue in cancer, stroke, and HIV using the functional assessment of chronic illness therapy-fatigue (FACIT-F) scale, Journal of Psychosomatic Research, 2013, 74(1), 64-8.

31. Courtier, N, Gambling, T, Enright, S, Barrett-Lee, P, Abraham, J, Mason, MD, Psychological and immunological characteristics of fatigued women undergoing radiotherapy for early-stage breast cancer, Supportive Care in Cancer, 2013, 21(1), 173-81.

32. Banipal, RPS, Singh, H, Singh, B. Assessment of cancer-related fatigue among cancer patients receiving various therapies: A crosssectional observational study, Indian Journal of Palliative Care, 2017, 23(2), 207-11

33. Mota, DDCdF, Pimenta, CAdM, Caponero, R, Fatigue in colorectal cancer patients: prevalence and associated factors, Revista LatinoAmericana de Enfermagem, 2012, 20(3), 495-503.

34. Walsh, D, Donnelly, S, Rybicki, L, The symptoms of advanced cancer: relationship to age, gender, and performance status in 1,000 patients, Supportive Care in Cancer, 2000, 8(3), 175-9.

35. Servaes, P, van der Werf, S, Prins, J, Verhagen, S, Bleijenberg, G, Fatigue in disease-free cancer patients compared with fatigue in patients with chronic fatigue syndrome, Supportive Care in Cancer, 2001, 9(1), 11-7.

36. Kandasamy, A, Chaturvedi, S, Desai, G, Spirituality, distress, depression, anxiety, and quality of life in patients with advanced cancer, Indian Journal of Cancer, 2011, 48(1), 55-9.

http://edergi.cbu.edu.tr/ojs/index.php/cbusbed isimli yazarın CBU-SBED başlıklı eseri bu Creative Commons Alınt1-Gayriticari4.0 Uluslararası Lisansı ile lisanslanmıştır. 